\title{
Comparative Analysis of Disabled Accessibility Needs of Heritage Building in Perak
}

\author{
${ }^{1}$ Nurul Fadzila Zahari, ${ }^{2}$ Saidatul Farhana Harun, ${ }^{3}$ Nur Azfahani Ahmad, ${ }^{4}$ Zuraihana Ahmad Zawawi, ${ }^{5}$ Nuzaihan Aras Agus \\ Salim \\ 1,2,3,4 Faculty of Architecture, Planning and Surveying, Universiti Teknologi MARA, Seri Iskandar Campus, Seri Iskandar, 32610, Perak, \\ Malaysia \\ ${ }^{5}$ Pusat PengajianPerumahan, Bangunan dan Perancangan, Universiti Sains Malaysia, 11800 USM, Pulau Pinang
}

\begin{abstract}
Tourism sector was the sixth highest national income provider to the Malaysian economy in 2014. In order to replenish Malaysian economy through tourism, the Malaysian government has to diversify the present tourism products and offers a wide variety of tourism packages. This has mentioned in the National Key Results Area (NKRA) development platform highlighted in the 10th Malaysian Plan. Therefore, the tourism sector needs to continuously re-engineer and adapt its business model to suit every customer's needs and demands, including disabled people. At the moment, one of the highest tourist attraction contributors in Malaysia is the heritage building sector. The heritage building sector in Malaysia becomes popular due to its diverse historical background and culture. It attracts local and international tourists to visit. However, the lack of facilities provided especially for the disable people has hindered its future prospects to become globally popular. The national heritage should be viewed, explored and enjoyed by everybody without discriminating anyone. Insufficient of provision for disable facilities in heritage act has caused barrier to the disable people to enjoy and visit the heritage sites. The objective of this research is to analyze the comparative data that been retrieved in the field of selected case study. It will be carried out by visiting the selected case study, observation and documentary analysis. This research aims to do a comparative analysis of Disabled Accessibility needs of Heritage Building in Perak. The findings of this research will alert the needs of disabled in visiting the heritage building and documented for future research.
\end{abstract}

\section{Introduction}

Heritage building used to be described as inheritance of knowledge define within the social, political and culture context from the past (Graham, 2002). According to Harun, 2011, our Department of National Heritage has listed numerous buildings and monuments been protected, preserved and conserved from early 1990 to 2000. This shows increasing of awareness and understanding the practice and value of Heritage Building. A few methods frequently used to protect all this heritage buildings as stated in National Heritage Act, 2005 such as preservation, repair and maintenance, restoration, reconstruction, rehabilitation, adaptation and adaptive reuse or any combination of those processes.

Heritage building sector in Malaysia become popular due to its diverse historical background and culture. It attracts local and international tourists to visit. At the moment, one of the highest tourist attraction contributors in Malaysia is the heritage building sector (NKRA, 2015). However, the lack of facilities provided especially for the disable people has hindered its future prospects to become globally popular. The national heritage should be

\footnotetext{
${ }^{a}$ Corresponding author: nfz7883@gmail.com
}

viewed, explored and enjoyed by everybody without discriminating anyone. Insufficient of provision for disable facilities in heritage act has caused barrier to the disable people to enjoy and visit the heritage sites.

Malaysia's policies and programs for the disabled citizens of the country are guided by the strategic goals of the National Welfare Policy, which emphasizes on the attainment of self-reliance, equalization of opportunities for the less fortunate and fostering of the spirit of mutual help and support towards enhancing a culture of caring.

\section{Literature Review}

\subsection{Heritage}

National Heritage Act 2005, defines heritage as any heritage site, heritage object, underwater cultural heritage or any living person declared as National Heritage as stated under section 67. Heritage can be divided into two categories which are Cultural heritage and Natural Heritage. 
In order to ensure the historical buildings are protected and the authenticity being preserved as it original form, the international conservation guidelines and charters such as ICOMOS Australia, 1981 and United Kingdom Institute of Conservation (UKIC, 1983) has provide the conservation principle and standard which base on ethical code. The basic principles and standards of conservation which contain in international charters are:

i. Careful recording and research before intervention

ii. Minimum alteration of historic building's fabric

iii. Minimum risk of significant loss, damage or uncertainty in performance through intervention.

iv. Distinctive or distinguishable use of new and additional material

v. Longevity in finished work

The awareness of the importance of historic buildings among Malaysian is growing thus the national heritage should have been preserved accordingly by using the international charters and local guidelines (Harun, 2011). However, at the moment, there are limited provision established for disable people which have hinder them to visit this historical buildings. A research has shown that in comparing Malaysia and Singapore to the developed countries such as United Kingdom and Australia which had established Guideline in Improving Accessibility in Heritage Environment, as to improve the equality of person with disabled's (PWDs) right in accessing the heritage building. The differences in implementation of barrier-free in historic building and places are rather large between developed and developing country such as Malaysia. The policies in Malaysia regarding PWDs and accessibility in Heritage Environment may not reach the level of that in developed countries such as United Kingdom and Australia. This matters of policies should be taken seriously by government as it will ensure the equal right to enjoy and learn from historic building and places and in the same time it will increase the market for tourism (Marsin, Ariffin and Shahminan, 2014).

\subsection{Person with Disabilities}

According to World Health Organization (WHO, 2008), disabled people is a person or an individual with disabilities such as an impairment of problem in body function or structure; an activity limitation is a difficulty encountered by an individual in executing a task or action; while a participation restriction is a problem experienced by an individual in involvement in life situations. Disability is thus not just a health problem (Abdul Rahim A. and Abd. Samad N.A, 2010). It is a complex phenomenon, reflecting the interaction between features of a person's body and features of the society in which he or she lives. Overcoming the difficulties faced by people with disabilities requires interventions to remove environmental and social barriers (Abdul Rahim A. and Abd. Samad N.A, 2010). Its supported by the statement of Malaysian Prime Minister in Malaysian Information Network and Disabilities, 2010 which is 'apart from new buildings, existing buildings and public amenities, the local authorities would provide guidelines to make this places friendly to Person with Disabilities (PWDs) to cater their needs. Its clearer when Ch'ng, 2010 in his paper suggested that the current legislation is not sufficient for local authority to monitor the needs of PWDs in built environment industry in Malaysia.

However, at the moment, the disable people are being neglected from this group due to lack of access and facilities provided. Additional features on having access and facilities for PWDs shall not change the whole view of the heritage building but complimenting with the important activity in conserving the heritage buildings (Yaacob and Hashim, 2007).

\subsection{International and Local Guidelines for Disabled Accessibility}

Person with Disable Act came into forces in 2008 to recognize the importance of accessibility to the physical, social, economic, cultural environment, health, education as well as to communication and information enables the PWDs to full participate in society. Section 26 of PWD Act emphasized that PWDs shall have rights to access to and use of public facilities, amenities, services and buildings open or provided to the public on equal basis with persons without disabilities.

A proposal paper to upgrade services of PWDs for an accessible environment was tabled by the Minister to the National council for address local Authority to implement the laws especially in the Uniform Building By Law 34A (UBBL 34A) (Hussein and Yaacob, 2013). The Street, Drainage and Building Act 1974 was amended in 1991 to include By Law 34A of the UBBL34A. It was gazette by the state governments between 1992 and 1996. Uniform Building by Law 1984 (UBBL 1984) By Law 34A stated that a building must be accessible to disabled persons. A few standards were introduced such as Malaysian Standard MS 1183 (Specifications for Fire Precautions in design and Construction of buildings Part 8: Code of Practice for means of Escape for PWDs), and MS 1184 (Code of Practice for Access for PWDs in Building) and MS 1331 (Code of Practice for Access PWDs Outside Building). The Equality Act 2010 of United Kingdom gives people from discrimination in ranges of areas including accessing the services, education and employment. An organization cannot discriminate which means they need to provide or adapt their premises to allow disabled person to access services and employment. In pursuing the act, the Historic England recognizes that everyone should able to enjoy the access to the historic environment which later they introduced the guidelines of Easy Access to Historic Building to enable PWDs to enjoy their heritage environment. Based on Berkshire Accessibility by Design (2010) the building are divided into two which are Access to building and Access within building (referred to table 1). This design guidance encompasses almost aspect and element of building that can be adapted for disabled accessibilities.

Table 1: Accessible by Design, A Standard Guide, 2010

Design Guidance 


\begin{tabular}{|c|l|}
\hline 1. & Access to building \\
\hline a. & Car Parking \\
\hline b. & Routes \\
\hline c. & External ramps \\
\hline d. & External steps \\
\hline e. & Handrails \\
\hline 2. & Access within building \\
\hline a. & Entrances \\
\hline b. & Entrance doors \\
\hline c. & Entrance foyers \\
\hline d. & Circulation \\
\hline e. & Corridors \\
\hline f. & Internal doors \\
\hline g. & Surfaces \\
\hline h. & Internal \\
& \multicolumn{1}{c|}{- Stairs } \\
\hline i. & Passenger lifts \\
\hline j. & Platform lifts \\
\hline k. & Wheelchair platform stair lifts \\
\hline m. & WCs \\
\hline & Equipment such as wheelchair \\
\hline & \\
\hline
\end{tabular}

\section{Methodology}

This research used a qualitative method for excellent way of finalizing the result. The author use an observation method on selected case study to determine the disabled accessibility existed. These multiple case study were chosen according to the types and similarity of the typology of the heritage building. The selected case study are Museum Darul Ridzuan, Ipoh, Perak Museum, Taiping and Royal Museum at Kuala Kangsar. All selected case study are located in the state of Perak. All of them is two storey height and used as a museum. The variables are based on Berkshire Accessibility by Design, 2010 as it encompasses almost all elements of the building that can be adapted for Disabled Accessibility requirement. This variables used to compare with the selected multiple cases.

\section{Case Study}

The multiple selected case studies' background are summarized in table 2 .

Table 2: Summary of the selected multiple case studies.

\begin{tabular}{c|ccc} 
Case & Darul & Perak & Perak Royal \\
Study & $\begin{array}{c}\text { Ridzuan } \\
\text { Museum }\end{array}$ & Museum & Museum \\
\end{tabular}

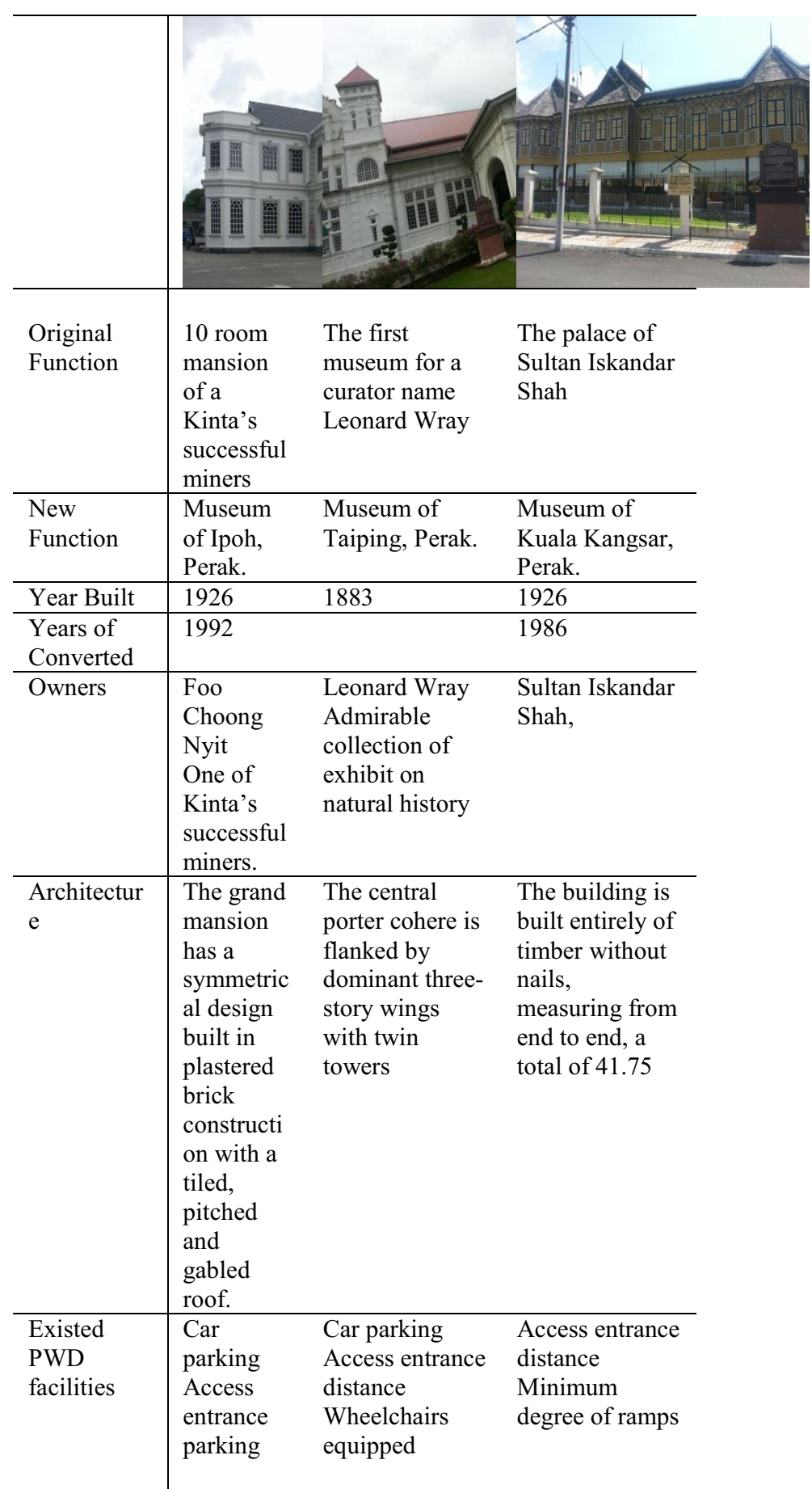

\section{Finding and Analysis}

The analysis of this research features comparative analysis on case studies with reference to the multiple selected case studies conducted in Perak. A comparative analysis is carried out to discuss the findings and observation on awareness of Disabled Accessibility at Heritage Building based on the case studies undertaken.

5.1 Comparative discussion of multiple cases.

\subsubsection{External Environments}

a) Car parking 
All of three case studies did have car park for the disabled. It shows that the management aware of the disabled visitors.

b) Routes

The external travel or routes for the three cases are defined and only underground roots of nearby big tree needed to be cut away.

c) External Ramps

Only Perak Royal museum does not has the external ramp due to the limitations of material used for the museum which is timber. The other two cases are complete with the external ramps.

d) External Steps

The external step are accordingly to the UBBL 1984 requirements which are $185 \mathrm{~mm}$ for the thread and $255 \mathrm{~mm}$ for the riser.

e) Handrails

The handrail are available in these three cases and compliance to the UBBL 1984 which is maximum height is $1100 \mathrm{~mm}$ and minimum of $900 \mathrm{~mm}$.

\subsubsection{Internal Environment}

a) Entrances

These multiple cases have sufficient width of entrance into the building. It is comfortable and ease the disabled to enter the building.

b) Entrance Doors

The entrance doors for Darul Ridzuan museum and Perak Museum have sufficient width and suitable material for doors. Meanwhile the Perak Royal Selangor Museum do not meet the requirement. Since the location of door is at the end of staircase without any ramp.

c) Entrance Foyers

For all these cases there are no entrance foyers space.

d) Circulation

The circulation of these multiple cases sufficient for the disabled to circulate inside the museum, except for the Perak Royal Museum due to the location of main entrance in the first floor.

e) Corridors

There is no corridor provided in these cases.

f) Internal doors

All of the cases had the internal doors.

g) Surfaces

The surfaces of these multiple cases good to walk, flat and ease the disabled to walk and using the provided equipment such as wheelchair and walker.

h) Internal

i. Stairs, Ramps and Handrails.

Only Perak Royal Museum does not has stairs and handrails due to the exhibition area are located on first floor. Ramp is only provided in Perak Museum.

i) Passenger lifts, Platform lifts, and wheelchair platform stair lifts

All these three requirement above were not provided by the management in these multiple cases.

j) WCs and Equipment as Wheelchair

Out of three case studies selected, only Perak Museum in Taiping provides WCs and equipment such as wheelchair.
Table 3: Comparative Result on Selected Multiple Case Studies

\begin{tabular}{|c|c|c|c|c|}
\hline & Design Guidance & \multicolumn{3}{|c|}{ Case Study } \\
\hline & & $\begin{array}{c}\text { Darul } \\
\text { Ridzuan } \\
\text { Museum }\end{array}$ & $\begin{array}{c}\text { Perak } \\
\text { Museum }\end{array}$ & $\begin{array}{c}\text { Perak } \\
\text { Royal } \\
\text { Museum }\end{array}$ \\
\hline 1. & $\begin{array}{l}\text { External } \\
\text { Environment }\end{array}$ & & & \\
\hline a. & Car Parking & $\sqrt{ }$ & $\sqrt{ }$ & $\sqrt{ }$ \\
\hline b. & Routes & $\sqrt{ }$ & $\sqrt{ }$ & $\sqrt{ }$ \\
\hline c. & External ramps & $\sqrt{ }$ & $\sqrt{ }$ & $\mathrm{X}$ \\
\hline d. & External steps & $\sqrt{ }$ & $\sqrt{ }$ & $\sqrt{ }$ \\
\hline e. & Handrails & $\sqrt{ }$ & $\sqrt{ }$ & $\sqrt{ }$ \\
\hline 2. & $\begin{array}{l}\text { Internal } \\
\text { Environment }\end{array}$ & & & \\
\hline a. & Entrances & $\sqrt{ }$ & $\sqrt{ }$ & $\sqrt{ }$ \\
\hline b. & Entrance doors & $\sqrt{ }$ & $\sqrt{ }$ & $\mathrm{X}$ \\
\hline c. & Entrance foyers & - & - & - \\
\hline d. & Circulation & $\sqrt{ }$ & $\sqrt{ }$ & $\bar{X}$ \\
\hline e. & Corridors & - & - & - \\
\hline f. & Internal doors & $\sqrt{ }$ & $\sqrt{ }$ & $\sqrt{ }$ \\
\hline g. & Surfaces & $\sqrt{ }$ & $\sqrt{ }$ & $\sqrt{ }$ \\
\hline $\mathrm{h}$. & $\begin{array}{l}\text { Internal } \\
\qquad \begin{array}{l}\text { - Stairs } \\
\text { - Ramps } \\
\text { - Handrails }\end{array}\end{array}$ & $\begin{array}{l}\sqrt{ } \\
X \\
\sqrt{ }\end{array}$ & $\begin{array}{l}\sqrt{ } \\
\sqrt{ } \\
\sqrt{ }\end{array}$ & $\begin{array}{l}X \\
X \\
\sqrt{ }\end{array}$ \\
\hline i. & Passenger lifts & $\mathrm{X}$ & $\mathrm{X}$ & $\mathrm{X}$ \\
\hline $\mathrm{j}$. & Platform lifts & $\mathrm{X}$ & $\mathrm{X}$ & $\mathrm{X}$ \\
\hline $\mathrm{k}$. & $\begin{array}{l}\text { Wheelchair } \\
\text { platform stair lifts }\end{array}$ & $\mathrm{X}$ & $\mathrm{X}$ & $\mathrm{X}$ \\
\hline 1. & WCs & $\mathrm{X}$ & $\sqrt{ }$ & $\mathrm{X}$ \\
\hline $\mathrm{m}$. & $\begin{array}{l}\text { Equipment such } \\
\text { as wheelchair }\end{array}$ & $\mathrm{X}$ & $\sqrt{ }$ & $\mathrm{X}$ \\
\hline
\end{tabular}

\section{Conclusion}

As conclusion, within three case studies selected, Perak Museum, Taiping, Perak had most of disabled accessibility provided. While Perak Royal Museum make the least provider of disabled accessibility. This is because the building itself are restricted based on the material used which is timber. It makes the building not ready to implement the disabled accessibility requirement. Improvising the accessible buildings and facilities are important to accommodate the tourist and visitors with different impairments. The heritage building also provided the common disabled accessibility such as parking space, toilet and wheel chair. Nevertheless, one 
of the selected case study do not has lift or platform to carry the disabled tourist to the upper floor.

This matters could hindered the tourist to bring their elderly to visit the building again. Furthermore, the current conservation guidelines and requirements are not comprehensive enough to address the disabled accessibility aspects as important criteria in conserving the heritage building which open to the public. For further recommendation, the author suggests to analyse the act, manual or guidelines of heritage in Malaysia purposely for disabled accessibility.

\section{References}

[1] A. A. Rahim (2010), Accessible built environment for the elderly and disabled in Malaysia: hotel as case studies, Malaysia.

[2] Accessibility by Design, A Standard Guide, Berkshire LABC Publishing Publication, 2010

[3] Bullen, P. \& Love. P. (2010). The rhetoric of adaptive reuse or reality of demolition: Views from the field. Cities. 27(4), pp. 215-224. Retrieved from DOI: 10.1016/j.cities.2009.12.005

[4] Christina B. (2011). Adaptive Reuse: Explaining Collaboration within Complex Process, published Master Thesis, University of Oregon, USA

[5] Cunnington, P. (1988). Change of Use. London, UK: A \& C Black Ltd.

[6] D.Urquhart (2007), Conversion of Traditional Buildings, Application of the Scottish Building Standard, Part 1 Principles and practice, published by Historic Scotland, Edinburgh.

[7] Douglas, J. Building Adaptation. Ed.: Elsevier Ltd., UK, 2006.

[8] Graham, B. (2002). Heritage as Knowledge: Capital or Culture". Urban studies, Volume 39, Nos 5-6, pg. 1003-1017.

[9] ICOMOS Australia. (1981). Charter for the conservation of Places of Cultural Significance (The Burra Charter), Australia ICOMOS Icn, Sydney.

[10] Ismail, Md. R., (2003). Country paper: Malaysia. Expert Group Meeting and Seminar on an International Convention to Protect and Promote the Rights and Dignity of Persons with Disabilities Bangkok, Thailand, 2-4 June 2003.

[11] Kamaruddin H., Muhammad Ariff N.R, Wan Ismail W.Z, A.F Bakri, Z. Ithnin, (2014). Malaysian Scenario on Access and Facilities for Persons with Disabilities: A Literature Review. Building Surveying, Facilities Management and Engineering Conference (BSFMEC)

[12] K. S. Kamal, Kerosakan Bangunan dan Penyataan Kaedah Kerja Pemuliharaan Bangunan Bersejarah, 2011

[13] Langston, C., F. Wong, E. Hui And L. Y. Shen Strategic assessment of building adaptive reuse opportunities in Hong Kong. Building and Environment, 2008, 43(10), 1709-1718.

[14] L. Ab. Wahab, Aplikasi Prinsip Penyesuaiangunaan terhadap Elemen Senibina Hotel Warisan di Tapak Warisan Dunia Melaka dan Georgetown, 2013
[15] N. H. Salleh, Fire safety and protection measures in heritage buildings with special consideration on museum buildings in Malaysia, 2012

[16] National Heritage Act 2005 (Act 645). (2005). Selangor D. E.: International Law Book Services.

[17] R.Prihatmanti and A.Bahaudin, 2011. Impacts of Adaptive Reuse In The UNESCO Listed Heritage Buildings, George Town, Penang. Retrieved from www.academia.edu on 26 November 2013.

[18] P.G.Tan, (2012), International Day of Person with disabilities 2012, 'The Digital Awakening, Living one more day' Blog $3^{\text {rd }}$ December 2012 (Retrieved on $5^{\text {th }}$ December 2013)

[19] R.C.C Wai (2008), Universal Design Considerations in Adaptive Reuse of Historic Building, HKIA Journal, Hong Kong.

[20] Regulation for Conservation Areas and Heritage Buildings by Municipal Council of Penang Island (PeraturanuntukKawasanPemuliharaandanBangunanbangunanWarisan - MajlisPerbandaranPulau Pinang)

[21] Sandra D. (2010), Removing the Obstacles (Disability Access and the Arts in Heritage Buildings, Accessible Arts, NSW, Australia.

[22] S. N. Harun, 2011.Heritage Building Conservation in Malaysia: Experience and Challenges, published in The $2^{\text {nd }}$ International Building Control Conference 2011 in Malaysia.

[23] S. N. Harun, 2011.Heritage Building Conservation in Malaysia: Experience and Challenges, published in The $2^{\text {nd }}$ International Building Control Conference 2011 in Malaysia.

[24] Social Welfare Department (2007), National Advisory and Consultancy Council for Persons with Disabilities Meeting. (Meeting notes, 11 September 2007).

[25] United Kingdom Institute of Conservation, (UKIC, 1983). The United Kingdom Guidance for Practice, UKIC, London.

[26] UNESCO (United Nations Educational, Scientific and Cultural Organisations( (1972). $7^{\text {th }}$ session at general conference. Convention concerning the protection of the world cultural and natural heritage. New York: United Nations. Retrieved 15 November 2010, from http://whc.unesco.org/archive/convention-en.pdf

[27] Uniform Building By Law, 1984 (amendment of 2012), Malaysia.

[28] United Nations (2006). Convention on the Rights of Persons with Disabilities. New York: United Nation Treaty Collection. [Online]. Available at: http://www.un.org/disabilities/convention/conventionfull. shtml [retrieved on June 2015].

[29] Yaacob, N.M. and Hashim, N.R. (2007). Inclusive heritage tourism: A study on the access needs of disabled and elderly tourists in Malaysia. The 3rd Tourism Outlook onference and Global Event Congress II, Kuala Lumpur, 227-239.

[30] Yaacob, N.M., Accessibility to historic and listed public buildings: The development control process in England and Wales, 2007 